\title{
Nutritional value of fermented and not fermented material of distiller's grains in pig nutrition*
}

\author{
R.-L. Huang' ${ }^{1}$ Y.-L. Yin ${ }^{1,3}$, K.-P. Wang ${ }^{2}$, T.-J. Li ${ }^{1}$ and J.-X. Liu ${ }^{2}$ \\ ${ }^{1}$ Changsha Institute of Agricultural Modernization, The Chinese Academy of Sciences \\ Hunan, Changsha, P.O. Box 10, Changsha 410125, People's Republic of China \\ ${ }^{2}$ Hunan Wangshi Biotechnology Inc. \\ Hunan, Changsha, 410011, People's Republic of China
}

(Received 6 November 2002; accepted 4 April 2003)

\begin{abstract}
Digestion and performance experiments were conducted to investigate the nutritional value of microbially fermented distiller's grains for growing pigs. Yorkshire $\mathrm{x}$ Landrace $\mathrm{x}$ Chinese Black pigs, with an average initial body weight (BW) of approximately $30 \mathrm{~kg}$ were used for both studies. The performance study was finished at a BW of approximately $60 \mathrm{~kg}$. The distiller's grains used in this study were the by-products of the Hunan Spirit Factory, in which sorghum and rice were the grains used for alcohol production. The material used for fermentation was a live bacteria (Hunan Wangshi Biotechnology Inc.) that can produce cellulase. Chemical analyses showed that the distiller's grain used in this study contained $170.8 \mathrm{~g} / \mathrm{kg}$ (in dry matter) of crude fibre, while the microbially fermented distiller's grains contained only $96.7 \mathrm{~g} / \mathrm{kg}$ of crude fibre. Meanwhile, crude protein was increased from 152.7 to $325.8 \mathrm{~g} / \mathrm{kg}$ by microbial fermentation. The microbially fermented distiller's grains also had higher $(\mathrm{P}<0.05)$ ileal apparent digestibility of crude fibre $(24.9$ vs $18.0 \%)$, crude protein $(74.5$ vs $41.9 \%$ ), amino acids, and faecal digestibility of energy (70.3 vs $61.3 \%$ ) than those of the distiller's grains. The performance results show that $10 \%$ of a maize-soyabean meal based diet can be replaced by microbially fermented distiller's grains, with no difference $(\mathrm{P}>0.05)$ in daily gain $(795 \mathrm{vs} 785 \mathrm{~g})$ or feed efficiency $(2.16$ vs 2.20$)$. However, the performance traits were affected $(\mathrm{P}<0.05)$ when the proportion of microbially fermented distiller's grains in the diet was over $10 \%$.
\end{abstract}

KEY WORDS: distiller's grains, fermented distiller's grains, nutritional value, pigs

\footnotetext{
* Supported by the Hundred Talents Project of The Chinese Academy of Sciences

${ }^{3}$ Corresponding author: e-mail: yyulong@hotmail.com
} 


\section{INTRODUCTION}

Distiller's grains (DG) are by-products of the alcohol distilling industry. Starch is decomposed to alcohol, so DG is enriched in protein. However, the crude fibre content is high (170-270 g/ $/ \mathrm{kg}$ ) according to Zhong et al. (1988) and Zhao (1996), because of the addition of a large amount of rice husk for improving distillation. This limits the utilization of distiller's grains as an animal feedstuff, especially for pigs due to its high content of fibre. China produces 290-300 million tons of dry DG annually. However, only $20 \%$ is used as an animal feedstuff and therefore the remainder is a source of environmental pollution (Yin et al., 1991). In order to reduce the fibre content, a screen method is usually used for separating the husks from the DG (Lou et al., 1996). However, this method has problems in terms of operation and labour costs. A technique for decomposing fibre with microorganisms was invented by Hunan Wangshi Biotechnology Inc. The objective of this study was to compare the nutritive value of microbially fermented DG with normal DG for growing pigs.

\section{MATERIAL AND METHODS}

\section{Distiller's grains}

One sample of the DG was collected from a white spirit factory in Hunan province (P.R. China), in which sorghum and rice were used for alcohol production. To prepare the microbially fermented DG, the same batch of DG, moistened to $40 \%$ water and $1 \mathrm{~g} / \mathrm{kg}$ of a preparation of live microorganisms producing cellulase was added (Hunan Wangshi Biotechnology Inc.). The compound was fermented for $12 \mathrm{~h}$ under ambient conditions. The end product of the fermentation was in the wet form. The chemical composition of the microbially fermented DG and normal DG is shown in Table 1. The fermented and not fermented DG used for the digestibility and performance studies were provided on air-dried basis.

\section{Digestibility experiment}

Eight Yorkshire $\mathrm{x}$ Landrace $\mathrm{x}$ Chinese Black barrows, with an average initial body weight (BW) of approximately $30 \mathrm{~kg}$, were subjected to an ileo-rectal anastomosis by the procedure described by Henning et al. (1986) and modified by Yin et al. (1993a,b). After surgery, the pigs were housed individually in stainless steel metabolism crates in a temperature-controlled barn $\left(20\right.$ to $\left.22^{\circ} \mathrm{C}\right)$. Pigs were fed a commercial pig starter diet during the 15 -d recovery period. On day 16 , the pigs were randomly allocated, in a two-period crossover design to one of two diets (Table 2). The normal DG and the microbially fermented DG diets were supplemen- 
ted $(\mathrm{g} / \mathrm{kg})$ at the same levels with dicalcium phosphate (5), limestone (10), mineral and vitamins (3) on a dry matter basis and fed (air-dry basis) to the pigs directly. The pigs were fed twice daily at 08.00 and $18.00 \mathrm{~h}$ at a rate of $4 \%$ (DM basis) of body weight. Each balance period consisted of a 7-d adaptation period and 6-d ileal digesta collection period. Digesta were collected quantitatively, pooled per pig, and frozen at $-18^{\circ} \mathrm{C}$ until freeze-drying. Eight intact pigs of the same breed, sex and age were used for determining the faecal digestibility of gross energy.

\section{Growth performance experiment}

One hundred Yorkshire $\mathrm{x}$ Landrace $\mathrm{x}$ Chinese Black pigs (50 gilts and 50 barrows), with an average initial body weight of approximately $27 \mathrm{~kg}$ were randomly divided among 20 different floor pens $\left(4.6 \mathrm{~m}^{2}\right)$ with 5 pigs in each pen. The animal house was a total confinement building in an environmentally controlled room with totally slatted floors. The feed was provided as mash; feed and water were available ad libitum.

The experimental design was a randomized complete block of five blocks and four treatments (diets; Table 2). The control diet contained ( $\mathrm{g} / \mathrm{kg}$ ) maize, 715 ; wheat bran, 100; soyabean meal, 145; and mineral and vitamin premix, 40. In the other three experimental diets, the proportion of maize, wheat bran and soyabean in the control diet was replaced by 10, 20 and 30\% microbially fermented DG (on DM basis), respectively. Individual pig weights and pen feed intakes were determined weekly. The experiment lasted for 41 days.

\section{Chemical analyses}

Samples were analyzed for DM, organic matter (OM), gross energy (GE), crude fibre (CF), Ca, P and crude protein (CP) according to AOAC (1990) methods. Amino acid (AA) compositions of samples were determined by derivatization with PITC (phenylisothiocyanate) and detection by fluorescence using a high performance liquid chromatograph (Pico-Tag, Waters, USA), after hydrolysis in $6 \mathrm{~N} \mathrm{HCl}$ in sealed vacuum tubes at $110^{\circ} \mathrm{C}$ for $24 \mathrm{~h}$. Methionine was determined as methionine sulphone after oxidation with performic acid.

\section{Statistical analysis}

Data from performance experiments were statistically analyzed by variance difference, and Duncan's multiple range tests were used to test differences between means. In the digestibility experiment, the $t$ test was used to estimate the significant differences between the fermented DG and normal DG by ANOVA procedures of Statistical Analysis Systems Institute (SAS, 1985). 
TABLE 1

Chemical composition of the normal distiller's grains and microbial fermented distiller's grains, g/kg DM

\begin{tabular}{lrr}
\hline \multirow{2}{*}{ Item } & \multicolumn{2}{c}{ Distiller's grains } \\
\cline { 2 - 3 } & normal & microbial fermented \\
\hline Organic matter & 895.60 & 860.89 \\
Crude fibre & 170.79 & 96.67 \\
Crude protein & 152.67 & 325.82 \\
Gross energy, Mcal/kg DM & 4.61 & 4.06 \\
Essential amino acids & & \\
arginine & 3.77 & 13.06 \\
histidine & 3.77 & 5.27 \\
methionine & 2.09 & 2.11 \\
phenylalanine & 8.48 & 11.90 \\
leucine & 13.40 & 10.74 \\
isoleucine & 6.18 & 10.21 \\
lysine & 5.97 & 9.90 \\
threonine & 4.40 & 11.06 \\
valine & 6.70 & 13.37 \\
Non-essential amino acids & & \\
alanine & & 14.74 \\
aspartic acid & 9.01 & 21.06 \\
glutamic acid & 8.38 & 58.34 \\
glycine & 31.41 & 10.32 \\
proline & 4.82 & 3.90 \\
serine & 3.35 & 15.27 \\
tyrosine & 5.86 & 6.63 \\
\hline
\end{tabular}

TABLE 2

Composition of diets for the growth performance experiment

\begin{tabular}{lrrrr}
\hline \multirow{2}{*}{ Item } & \multirow{2}{*}{ Control } & \multicolumn{3}{c}{ Microbial fermented distiller's grains, \% } \\
\cline { 3 - 5 } & & 10 & 20 & 30 \\
\hline Ingredients, g/kg as fed basis & & & & \\
$\quad$ maize & 715.0 & 646.0 & 577.0 & 508.0 \\
wheat bran & 100.0 & 87.0 & 74.0 & 61.0 \\
soyabean meal & 145.0 & 127.0 & 109.0 & 91.0 \\
$\quad$ microbial fermented & & 100.0 & 200.0 & 300.0 \\
$\quad$ distiller's grains & & 40.0 & 40.0 & 40.0 \\
premix & & & & \\
Chemical analysis, g/kg DM & & 147.4 & 150.4 & 154.5 \\
$\quad$ crude protein & 144.3 & 36.8 & 42.3 & 46.9 \\
crude fibre & 31.3 & 7.5 & 7.4 & 7.3 \\
lysine & 7.6 & 5.3 & 5.1 & 5.2 \\
threonine & 5.4 & 1.7 & 1.6 & 1.5 \\
methionine & 1.8 & 6.1 & 5.9 & 6.0 \\
Ca & 6.2 & 5.0 & 5.1 & 4.9 \\
P & 5.2 & & \\
\hline
\end{tabular}

${ }^{1}$ premix provided per kg diet: minerals: Ca 5.75 g, P 2.6 g, NaCl 3.5 g, Mn 27.5 mg, Fe 105 mg, Zn 105 mg, Cu 125 mg, I 0.6 mg. Vit. A 9000 I.U., Vit. D 1500 I.U. Vit. E 18 mg, Vit. K 1.5 mg, chorine chloride $250 \mathrm{mg}$, niacin $30 \mathrm{mg}$, calcium pantothenate $27.5 \mathrm{mg}$, riboflavin $9.4 \mathrm{mg}$, thiamine $1 \mathrm{mg}$, pyridoxine $1 \mathrm{mg}$, vit. $\mathrm{B}_{12} 25 \mathrm{ug}$, biotin $50 \mathrm{ug}$ and folic acid $0.5 \mathrm{mg}$ 


\section{RESULTS AND DISCUSSION}

The analyses of OM, GE, CP, CF and AA of the normal and fermented DG are shown in Table 1 . The DG were very similar in the concentration of OM. The CF in the microbial fermented DG was $74.1 \mathrm{~g} / \mathrm{kg}$ units lower than that in the normal DG. However, the fermented DG had higher CP and AA contents. The CP, lysine and threonine contents in the microbial fermented DG were $173.2,3.9,6.7 \mathrm{~g} / \mathrm{kg}$ units higher, respectively, that those in the normal DG. The chemical composition of the DG was quite variable due to the different grain proportions and level of rice husk supplementation during the spirit-making process. The crude fibre and crude protein varied from 15 to $40 \%$ and 13 to $30 \%$ on DM bases, respectively (Yin and Zhong, 1991; Zhao, 1996; NRC, 1998). Both the crude fibre and crude protein, including the amino acid contents of distiller's grains used in this study were lower than those reported by Yin and Zhong (1991), Zhao (1996) and NRC (1998). The reason is due to different grains being used for alcohol production, e.g. the chemical composition of the DG reported by NRC (1998) was accurate only for maize. The mechanism by which the crude protein and amino acid contents increased and crude fibre and gross energy decreased by microbial fermentation of DG is not clear. It might be due to increased microbial protein and amino acids coming from the fermentation process, in which the microorganism uses crude fibre for reproduction. However, further study is needed.

The apparent ileal digestibility of $\mathrm{OM}, \mathrm{CP}, \mathrm{CF}$ and $\mathrm{AA}$ and faecal digestibility of energy of normal DG and microbially fermented DG are presented in Table 3. The microbially fermented DG had higher $(\mathrm{P}<0.05)$ ileal digestibility of nutrients and faecal digestibility of energy than the normal DG used in this study, but also higher than reported by Yin et al. (1993b). The faecal digestibility of energy in the fermented DG was 9 units higher than that of normal DG. The apparent ileal digestibility of lysine, methionine and threonine were increased to 27,11 , and 38 units, respectively, by microbial fermentation. The reason for that might be due to the decrease in crude fibre content in the microbially fermented DG (Table 1). A higher $(\mathrm{P}<0.05)$ ileal digestibility of crude fibre $(18 \mathrm{vs} 25 \%)$ in the microbially fermented DG was also found in this study.

As an increase was found in both crude protein and amino acid contents and digestibility by microbial fermentation, the faecal digestible energy (DE) and digestible crude protein and amino acid contents in microbially fermented DG were higher than in normal DG (Table 4). As discussed previously, the crude fibre content in DG of this study was lower the values given in the literature (Yin and Zhong, 1991; Zhao, 1996; NRC, 1998) and therefore the DE and ileal digestible crude protein and amino acid contents were higher than those reported in the literature. The $\mathrm{DE}$ in the present DG was $0.71 \mathrm{Mcal} / \mathrm{kg}$ (DM basis) higher than that reported in the NRC (1998) and similar trend was seen for amino acids. 
TABLE 3

Apparent ileal digestibility (\%) of nutrients and faecal digestibility energy of the normal distiller's grains and microbial fermented distiller's grains

\begin{tabular}{lcc}
\hline \multirow{2}{*}{ Item } & \multicolumn{2}{c}{ Distiller's grains } \\
\cline { 2 - 3 } & normal & microbial fermented \\
\hline Dry matter & $47.8^{\mathrm{b}} \pm 0.79$ & $62.8^{\mathrm{a}} \pm 0.52$ \\
Organic matter & $51.9^{\mathrm{b}} \pm 0.81$ & $65.5^{\mathrm{a}} \pm 0.82$ \\
Crude fibre & $18.0^{\mathrm{b}} \pm 0.43$ & $24.9^{\mathrm{a}} \pm 0.82$ \\
Crude protein & $41.9^{\mathrm{b}} \pm 0.90$ & $74.5^{\mathrm{a}} \pm 0.52$ \\
Gross energy & $61.3^{\mathrm{b}} \pm 0.79$ & $70.3^{\mathrm{a}} \pm 0.65$ \\
Arginine & $47.6^{\mathrm{b}} \pm 0.26$ & $86.1^{\mathrm{a}} \pm 0.52$ \\
Histidine & $39.6^{\mathrm{b}} \pm 2.17$ & $67.5^{\mathrm{a}} \pm 0.01$ \\
Isoleucine & $39.3^{\mathrm{b}} \pm 0.78$ & $75.6^{\mathrm{a}} \pm 0.94$ \\
Leucine & $45.1^{\mathrm{b}} \pm 0.84$ & $51.5^{\mathrm{a}} \pm 0.75$ \\
Lysine & $46.1^{\mathrm{b}} \pm 0.35$ & $73.1^{\mathrm{a}} \pm 0.16$ \\
Methionine & $50.5^{\mathrm{b}} \pm 0.76$ & $61.7^{\mathrm{a}} \pm 0.55$ \\
Phenylalanine & $41.7^{\mathrm{b}} \pm 1.03$ & $69.7^{\mathrm{a}} \pm 1.05$ \\
Threonine & $40.8^{\mathrm{c}} \pm 1.29$ & $79.3^{\mathrm{a}} \pm 0.13$ \\
Valine & $41.2^{\mathrm{b}} \pm 0.54$ & $77.4^{\mathrm{a}} \pm 0.80$ \\
Proline & $67.9^{\mathrm{b}} \pm 0.86$ & $81.9^{\mathrm{a}} \pm 1.02$ \\
Alanine & $45.8^{\mathrm{b}} \pm 0.60$ & $75.1^{\mathrm{a}} \pm 0.29$ \\
Aspartic acid & $42.7^{\mathrm{b}} \pm 0.45$ & $80.3^{\mathrm{a}} \pm 0.02$ \\
Glycine & $41.0^{\mathrm{b}} \pm 0.54$ & $76.4^{\mathrm{a}} \pm 1.01$ \\
Glutamic acid & $53.4^{\mathrm{b}} \pm 0.68$ & $81.8^{\mathrm{a}} \pm 0.38$ \\
Serine & $46.3^{\mathrm{b}} \pm 1.35$ & $83.0^{\mathrm{a}} \pm 0.36$ \\
Tyrosine & $36.5^{\mathrm{b}} \pm 0.45$ & $66.2^{\mathrm{a}} \pm 0.64$ \\
\hline
\end{tabular}

${ }^{\mathrm{a}, \mathrm{b}}$ values in the same row without a common letter are significantly different $(\mathrm{P}<0.05)$

The influence of dietary treatment on growth performance is shown in Table 5. Pigs fed high levels (20 or 30\%) of the microbially fermented DG diets had a lower feed intake $(\mathrm{P}<0.05)$, daily gain and higher feed/gain ratio than the pigs fed the control diet. However, there was no difference $(\mathrm{P}>0.05)$ in performance between the pigs fed the control diet and the pigs fed the lowest proportion (10\%) of the microbial fermented DG diet. The main reason for that is due to diarrhoea in the pigs fed the high levels of the microbially fermented DG diet, which needs further investigation. Another reason for the poor growth performance of the pigs fed the high of level of the microbially fermented DG diet may be due to its higher level of crude fibre (Table 2). Crude fibre fills the gut more and also influences other physiological processes such as transit time, nutrient absorption and digestive secretions (Hanrahan and O'Grady, 1970; Kass et al., 1980; Yin et al., 2000, 2001a,b). Hanrahan and O'Grady (1970) observed that feed conversion efficiency was $13.3 \%$ when $40 \mathrm{~g} / \mathrm{kg}$ of wheat middling ( $8.3 \mathrm{~g} / \mathrm{kg}$ crude fibre) were included in the control diet. Kass et al. (1980) reported that a level of $400 \mathrm{~g} / \mathrm{kg}$ lucerne meal, resulting in a concentration of $311 \mathrm{~g} / \mathrm{kg}$ neutral detergent fibre (NDF) in the diet for 
TABLE 4

Ileal digestible dry matter, organic matter, energy, crude protein and amino acid contents of the normal distiller's grains and the microbial fermented distiller's grains, $\mathrm{g} / \mathrm{kg}$ DM

\begin{tabular}{lcc}
\hline & \multicolumn{2}{c}{ Distiller's grains } \\
\cline { 2 - 3 } Item & normal & microbial fermented \\
\hline Dry matter & 477.6 & 628.3 \\
Organic matter & 464.6 & 564.1 \\
Crude protein & 64.0 & 242.6 \\
Gross energy, Mcal/kg & 2.8 & 2.9 \\
Arginine & 1.8 & 11.3 \\
Histidine & 1.5 & 3.6 \\
Isoleucine & 2.4 & 7.7 \\
Leucine & 6.0 & 5.5 \\
Lysine & 2.8 & 7.2 \\
Methionine & 1.1 & 1.3 \\
Phenylalanine & 3.5 & 8.3 \\
Threonine & 1.8 & 8.8 \\
Valine & 2.8 & 10.4 \\
Proline & 2.3 & 3.2 \\
Alanine & 4.1 & 11.1 \\
Aspartic acid & 3.6 & 16.9 \\
Glycine & 2.0 & 7.9 \\
Glutamic acid & 16.8 & 47.7 \\
Serine & 2.7 & 12.7 \\
Tyrosine & 1.5 & 4.4 \\
\hline
\end{tabular}

TABLE 5

Growth performance of the growing pigs fed various concentration of the microbial fermented distiller's grains

\begin{tabular}{lcccc}
\hline \multirow{2}{*}{ Item } & \multirow{2}{*}{ Control } & \multicolumn{3}{c}{ Microbial fermented distiller's grains, $\%$} \\
\cline { 3 - 5 } & & 10 & 20 & 30 \\
\hline Initial weight, kg & $27.6^{\mathrm{a}} \pm 2.8$ & $28.3^{\mathrm{a}} \pm 2.7$ & $28.3^{\mathrm{a}} \pm 3.5$ & $28.3^{\mathrm{a}} \pm 2.9$ \\
Final weight, kg & $60.6^{\mathrm{a}} \pm 5.5$ & $60.9^{\mathrm{a}} \pm 6.3$ & $56.8^{\mathrm{b}} \pm 5.7$ & $46.7^{\mathrm{c}} \pm 4.3$ \\
Average daily gain, g & $785^{\mathrm{a}} \pm 78$ & $795^{\mathrm{a}} \pm 110$ & $693^{\mathrm{b}} \pm 80$ & $448^{\mathrm{c}} \pm 76$ \\
Average daily feed intake, g & $1730^{\mathrm{a}} \pm 35$ & $1720^{\mathrm{a}} \pm 45$ & $1600^{\mathrm{b}} \pm 40$ & $1100^{\mathrm{c}} \pm 30$ \\
Feed/gain ratio & $2.20^{\mathrm{c}} \pm 0.21$ & $2.16^{\mathrm{c}} \pm 0.08$ & $2.31^{\mathrm{b}} \pm 0.76$ & $2.46^{\mathrm{a}} \pm 0.27$ \\
\hline
\end{tabular}

${ }^{\mathrm{a}, \mathrm{b}, \mathrm{c}}$ values in the same row without a common letter are significantly different at $\mathrm{P}<0.05$

growing pigs significantly affected the daily gain and feed conversion efficiency compared with the control diet ( $228 \mathrm{~g} / \mathrm{kg}$ of NDF). The average daily gain was reduced from 700 to $520 \mathrm{~g}$ and feed conversion efficiency increased from 3.23 to 4.91 compared to the control diet.

In summary, it can be concluded that microbially fermented distiller's grains had a reduced crude fibre content and increased crude protein content. The maize, wheat bran and soyabean based diet can be partly, up to $10 \%$, replaced by microbially fermented distiller's grains in pig nutrition. 


\section{REFERENCES}

AOAC, 1990. Association of Official Analytical Chemists, Official Methods of Analysis. 16th Edition, Washington, DC

Hanran T.J., O'Grady J.F., 1970. Pollard as an energy source in the diet of growing-finishing pigs. Irish J. Agr. Res. 44,133-135

Henning U., Noel R., Herrmann U., Wünsche J., Mehnert E., 1986. Nutrition-physiologic studies in pigs with ileo-rectal anastomoses. Arch. Anim. Nutr. 36, 585-592

Kass L.M., Van Soest P.J., Pond W.G., Lewis B., McDowell R.E., 1980. Utilization of dietary fiber from alfalfa by growing swine. J. Anim. Sci. 50, 175-191

Lou X.H., Zhao J., Tan Q.M., Zhang Y.L., Zhou T.Y., 1996. The performance of broiler chicks with distiller's grains. China Feed. 3, 16-19

Ministry of Agriculture, Fisheries and Food, 1986. The Analysis of Agricultural Materials. ${ }^{\text {rd }}$ Edition. Her Majesty's Stationery Office, London

National Research Council (NRC), 1998. Nutrient Requirements of Domestic Animal. Nutrient Requirements of Pigs. ${ }^{\text {th }}$ Edition. National Academy of Science, Washington, DC

Statistical Analysis Systems Institute (SAS), 1985. SAS User's Basics, Version 4 Edition. SAS Institute Inc., Cary, NC

Yin Y.L., Baidoo S.K., Liu K.Y.G., Schulze H., Simmins P.H., Jin L.Z., 2001b. The effects of different carbohydrase and protease supplementation on apparent (ileal and toal-tract) digestibility of nutrients of five hulless barley in young pigs. Livest. Prod. Sci. 71, 109-120

Yin Y.L., Baidoo S.K., Schulze H., Simmins P.H., 2001a. Effects of supplementation of diets containing hulless barley varieties having different level of non-starch polysaccharides with $\beta$ - glucanase and xylanase on the physiological status of the gastrointestinal tract and nutrient digestibility of weaned pigs. Livest. Prod. Sci. 71, 97-107

Yin Y.L., Huang R.L., Zhong H.Y., 1993a. Comparison of the ileo-rectal anastomomsis method for the measurement of ileal digestibility of protein sources and mixed diets in growing pigs. Anim. Feed Sci. Tech. 42, 297-303

Yin Y.L., McEvoy J.D.G., Schulze H., Henning U., Souffrant W.B., McCracken K.J., 2000. Apparent digestibility (ileal and overall) of nutrients and endogenous nitrogen losses in growing pigs fed wheat or its by-products without or with xylanase supplementation. Livest. Prod. Sci. 62, 119-132

Yin Y.L., Zhong H.Y., 1991. Study on the value of nutrition of distiller's grains for pigs. Develop. Prot. Natur. Resour. 7, 52-54

Yin Y.L., Zhong H.Y., Huang R.L., Chen C.M., Li T.J., Pan Y.F., 1993b. Nutritive value of feedstuffs and diets for pigs: I. Chemical compostion. Anim. Feed Sci. Tech. 44, 1-27

Zhao S.X., 1996. Study on the protein feedstuff from distiller's grains. China Feed. 1, 29-30

Zhong Z.Q., Wang K.Q., 1988. Utilization of the distiller's grains. Feed Res. 7, 25-27 


\section{STRESZCZENIE}

\section{Wartość pokarmowa przefermentowanego bądź nieprzefermentowanego wywaru z sorgo i ryżu dla świń}

Celem przeprowadzonych doświadczeń było oznaczenie wartości pokarmowej przefermentowanego wywaru zbożowego oraz wyników produkcyjnych rosnących świń jorkszyr x zwisłoucha $\mathrm{x}$ chińska czarna karmionych tą paszą. Przeprowadzono dwa doświadczenia na świniach o początkowej m.c. około $30 \mathrm{~kg}$, wzrostowe kończono przy m.c. około $60 \mathrm{~kg}$. Zastosowany wywar był ubocznym produktem pochodzącym z wytwórni spirytusu, produkowanego z sorgo i ryżu. Do fermentacji użyto bakterii wytwarzających celulazę. Wywar zawierał $170,8 \mathrm{~g} / \mathrm{kg}$ s.m. włókna, podczas gdy przefermentowany $96,7 \mathrm{~g} / \mathrm{kg}$, a zawartość białka ogólnego wzrosła z 152,7 do 325,8 g/kg. Pozorna strawność jelitowa wywaru przefermentowanego i nieprzeferntowanego wynosiła odpowiednio: włókna 24,9 i 18,0\%, białka ogólnego 74,5 i 41,9\%, energii brutto 70,3 i 61,3\%, przy czym różnice były statystycznie istotne $(\mathrm{P}<0,05)$. Podobnie strawność aminokwasów wywaru przefermentowanego była większa $(\mathrm{P}<0,05)$ niż nieprzefermentowanego.

Wyniki produkcyjne wskazują, że 10\% śruty z kukurydzy i soi dawek dla świń można zastąpić przefermentowanym zbożem (sorgo, ryż) uzyskując podobne $(\mathrm{P}>0,05)$ przyrosty masy ciała $(795 \mathrm{i}$ $785 \mathrm{~g} /$ dzień) oraz wykorzystanie paszy $(2,16$ i 2,20$)$. Większy dodatek tego wywaru wpłynął ujemnie $(\mathrm{P}<0,05)$ na wyniki produkcyjne. 